\title{
Factors Influencing Grape Juice Quality
}

Justin R. Morris

AdDitional INDEX WORDs. preharvest factors, anthocyanin, mechanical harvesting, vineyard mechanization, postharvest handling, hot press, cold press, evaporators, freeze concentration

Summary. Interest in grape juice has risen as the public becomes more aware of natural foods and the specific evidence of healthful benefits of grapes. Among major preharvest conditions that influence quality of grape juice are climate, soil, cultivar, vineyard management, and maturity. Each of these factors exerts its own influence, but complex interactions among these factors must be recognized. For mechanically harvested juice grapes, cultivar takes on special importance to quality and yield as do the production system, harvest machines, postharvest handling systems, and processing method. Grape juice composition has been extensively studied, and production and processing methods have improved over the years. The following discussion deals with developments in grape juice production.

$\mathrm{I}$ nterest in grape juice has risen as science continues to uncover health ful benefits of the consumption of grape juice and wine made from grapes (Blevins and Morris, 1997). Resveratrol, a naturally occurring fungus fighter in grapes, is present in wine (Threlfall and Morris, 1997). Ector et al. (1996) found resveratrol in unfiltered muscadine juice. Resveratrol is being credited in ongoing research with the ability to act as an antioxidant in the body to lower human cholesterol (Frankel et al., 1993), perform as a cancer chemopreventive (Jang et al., 1997), and aid in blood thinning (Pace-Asciak et al., 1995). The annual consumption of grape juice in the United States has gone from $5.3 \mathrm{oz}(0.16 \mathrm{~L})$ per person in 1930 to $16 \mathrm{oz}(0.47 \mathrm{~L})$ in 1979 to $27 \mathrm{oz}(0.73 \mathrm{~L})$ today.

Grape juice is a totally American product. The first grape juice was prccessed in the United States and used as the sacrament in Vineland, N.J. Thomas B. Welch, a dentist, processed the first grape juice by using the science of pasteurization developed by Louis Pasteur. This kept the juice stable and prevented fermentation. The juice was derived from 'Concord' grapes (Vitis labruscana L.) harvested from his backyard vineyard. In 1869, Welch cooked 'Concord' grapes in his kitchen, squeezed the juice through cloth bags, and filtered the liquid into bottles. He then plugged the bottles with cork and wax and immersed them in boiling water, destroying the yeast and preventing fermentation. $\mathrm{He}$ called his new product "Dr. Welch's Unfermented Wine." Orders for the juice, mainly for communion, increased until most of Welch's time was devoted to preparing grape juice (Chazanof, 1977).

Distinguished professor and director, Institute of Food Science and Engineering, University of Arkansas, Fayetteville, AR 72704. Published with the approval of the director of the Arkansas Agricultural Experiment Station as manuscript 97099 . The cost of publishing this paper was defrayed in part by the payment of page charges. Under postal regulations, this paper therefore must be hereby marked advertisement solely to indicate this fact. 
Charles Welch, Thomas Welch's son, took over the grape juice endeavor in 1872 , and it was soon a full-time operation. In 1896 , he moved his business to a large grapegrowing area at Watkins Glen, N.Y. In 1897, he built a plant in Westfield, N.Y., where he processed 300 tons $(272 t)$ of grapes in his first year and 3000 tons $(2723 \mathrm{t}) 5$ years later (Tressler, 1971).

\section{Grape juice composition and processing}

Composition of grape juice has been long and closely studied. Sugars found in 'Concord' grapes are glucose, fructose, and sucrose, and the major nonvolatile acids found are tartaric and malic (Montgomery et al., 1982). Although glucose and fructose are the major sugars present in grape juice, Hartmann and Tolman (1918) found that in some samples as much as one-third of the total sugar may be sucrose. Sugars, acids, methyl anthranilate, and o-aminoacetophenone (in Vitis labruscana and Vitis rotundifolia Michx.), volatile esters, alcohols, and aldehydes are major flavor constituents. The Welch Grape Juice Company (currently known as Welch's) reports that, in addition to the mineral elements of sodium, potassium, calcium, phosphorus, iron, copper, and manganese, grapes contain the organic substances biotin, niacin, inositol, pantothenic acid, pyridoxine hydrochloride, thiamine, folic acid, ascorbic acid, choline, and trace amounts of riboflavin and vitamin $B_{12}$. Berg (1940) demonstrated such enzymes as invertase, oxidases, and protopectinase also to be present in significant amounts. Sastry and Tischer (1952) isolated chlorophyll, carotenes, anthocyanin, and water-soluble yellow pigments from 'Concord' grapes.

According to Robinson et al. (1949), the quality of grape juice largely depends upon sugar level, acid content, and flavor constituents such as methyl anthranilate and other volatiles and phenolics. Changes that occur in grapes during growth, maturation, and processing determine quality of the juice.

According to Pederson (1971) and Cash et al. (1977), the principal acids of 'Concord' grape juice are tartaric, malic, and citric, but small quantities of other acids are present. The tartaric acid may be in the form of free tartaric acid or its salts. Fuleki et al. (1993) found the following ranges of acid concentrations (in $\mathrm{g} \cdot \mathrm{L}^{-1}$ ): tartaric, 4.19 to 13.51 ; malic, 1.68 tol5.36; citric, 0.30 to 1.16 ; lactic, 0.015 to 0.388 ; and succinic, 0.002 to 0.075 . Vitis rotundifolia (muscadine grapes) have been shown to contain ellagic acid, in addition to the above substances (Boyle and Hsu, 1990). Because this acid can form an undesirable precipitate in the bottle, recent research has been focused on factors that affect the extent of ellagic precipitation and ways to reduce it (Garrido et al., 1993; Lin and Vine, 1990). However, it has been suggested that ellagic acid may act as an anticarcinogen (Maas et al., 1991).

Flavor and aroma develop during the ripening process. Aroma of grapes consists of many volatile organic compounds. Methyl anthranilate, which produces an aroma similar to that of 'Concord' grapes, was one of the first compounds associated with odor character of a particular grape species. Other species of American grapes also contain anthranilic esters but at levels much lower than those in 'Concord' grapes. In addition to methyl anthranilate, the "foxy" aromas in V. lubruscana and $V$. rotundifolia grapes may be due to the presence of o-aminoacetophenone (Acree et al., 1990).

Color in grape juice is the result of anthocyanin pigments located in and near the skin. Ribereau-Gayon (1959) reported that the types and quantities of anthocyanin pigments are different among grape species. Differences in the types of anthocyanin help to explain why some grapes have better color stability and are more suitable for juice processing than others (Johnston and Morris, 1996). Muscadine grapes contain only the nonacylated 3,5-diglucosides (Flora, 1978; Lamikanra, 1988; Sims and Morris, 1985). Diglucoside anthocyanins are more susceptible to browning than monoglucosides. Morris (1981) observed that one of the major problems with muscadine grape products was the instability of the diglucoside anthocyanins, which causes juice to lose its color over time. The $V$. vinifera cultivars contain primarily acylated and nonacylated mono-glucoside anthocyanins (RibereauGayon, 1959; Nagel and Wulf, 1979), and V. labruscana cultivars contain a mixture of acylated and nonacylated mono- and diglucoside anthocyanins (Ribereau-Gayon, 1959; Goldy et al., 1986). White grape juice contains minor pigments such as chlorophyll and carotenes, which are important to color quality.

In general, as fruit matures, the sugar and color increase and the titratable acidity decreases. Specific composition of juice from any grape species can never be assumed since composition varies from year to year and changes continually during ripening. Likewise, the composition of a given species and cultivar will vary from area to area depending on soil, location, and climatic conditions.

Five major contributors to the quality of grape juice are the 1) cultivar, 2) production system, 3) machines used to harvest, 4) postharvest handling systems, and 5) processing method. 


\section{Cultivar}

Most of the unfermented grape juice consumed in the United States is made from 'Concord' grapes grown chiefly in Washington, New York, Michigan, Ohio, Pennsylvania, and Arkansas (Morris and Striegler, 1996). The United States accounts for the vast majority of the world's 'Concord' production, with Washington supplying one third of the world's Concords. 'Concord' and 'Niagara' grapes are also produced in Canada, primarily in Ontario along the Great Lakes. In 1993, the Arkansas Agricultural Experiment Station announced the release of a new juice grape cultivar, Sunbelt (Moore et al., 1993). This cultivar fulfilled the need for a 'Concord'-like processing grape that can be grown in southern areas where it does not show the 'Concord' problem of uneven ripening associated with high temperatures (Cawthon and Morris, 1983). In addition, large quantities of grape juice concentrate are produced in California from $V$. vinifera grapes.

The juice of muscadine grapes ( $V$. rotundifolia) has a unique aroma that is appreciated by some people, especially in the southern United States, where the species is native and its flavor is well known. Cultivars vary in color from almost white (bronze such as Carlos) to pink, red, blue, purple (Noble), and nearly black. Blends have a beautiful color and a refreshing taste (Sistrunk and Morris, 1985).

\section{Production}

Ease or difficulty of maximum vineyard mechanization depends upon the training system and the type and condition of the trellis system and wire. The Geneva doublecurtain training system developed by Shaulis et al. (1966) and the bilateral cordon training system have a design that allows maximum accessibility of the fruit to the shaking mechanism of the harvester and effective mechanical shoot positioning and pruning. A properly trained vine provides efficient machine operations without excessive damage to the vines or reduction of fruit yield or quality (Dale et al., 1995).

'Concord' is a vigorous growth cultivar. Irrigation and crop adjustment are two aids in producing a high quality, high-yield harvest (Morris, 1996). Irrigation should be seen as the use of available water resources to prevent rather than relieve moisture stress. Operating within this concept, research has shown that irrigation not only increases yields in dry summers by as much as $20 \%$ for some cultivars, but also its effects carry over to subsequent years. In years with normal rainfall, yields tend to be higher in vineyards that have been irrigated in previous years.

Horlechnology • October-December 1998 8(4)
Cultivars with vigorous growth can set such a large crop that the vines are weakened and unable to mature a large crop. Pruning and shoot or fruit thinning are two common methods of restoring a vineyard to a healthy, profitable crop load. University of Arkansas researchers reported that mechanical pruning of grape vines could be accomplished and would reduce pruning labor by as much as $50 \%$ (Morris et al., 1975). One viticultural concern was observed in this early research: the impossibility of treating each vine individually (balance pruning according to vine size), which might result in overcropping or undercropping of individual vines. Recent research at the University of Arkansas has shown that a mechanical thinner can eliminate this concern (unpublished data). This mechanical thinning unit uses bow rods on an over-the-row side mounted beater unit built so that the operator can see to adjust the fruit load on individual vines.

\section{Mechanization}

Most grapes used for juice are mechanically harvested. Many commercial over-therow harvesters use pivotal strikers, which are a double bank of flexible horizontal rods that strike and shake the vine to remove fruit (Fig. 1). Other commercial machines use a trunk shaker or pulsating-harvester concept in which two parallel rails impart horizontal vibrations manufacturers have combined the two principles and reduced the number of horizontal bars.

Morris (1985b) has shown that mechanically harvested grapes are of better quality than hand-harvested grapes. In a cooperative research effort with Tom Oldridge, a grape grower from Lowell, Ark., Morris has developed a system for vineyard mechanizato the upper trunk (Morris, 1990). Some

Fig. 1. View of the beater mechanism of a mechanical grape harvester that has been adapted for harvesting Geneva double-curtain trellised vines. Many harvesters are equipped with quad or bow rods that remove the fruit with less damage to the vines.

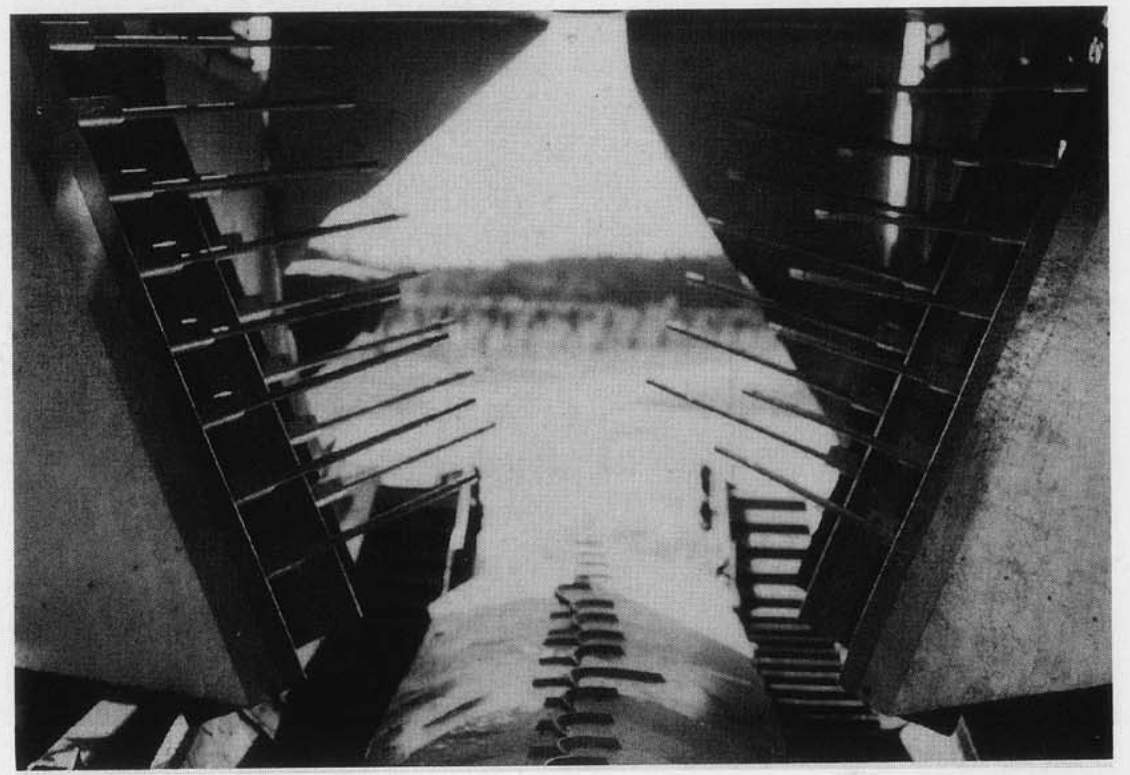


tion. The Morris-Oldridge System provides a system of machines for an almost complete mechanization of all vineyard operations (pending patent application) for 12 different trellising systems and methods to modify, trellis, and train grapevines. This patent is the result of studies at the University of Arkansas over the last 32 years that have involved the evaluation of trellising and training systems suitable for total vineyard mechanization, mechanical shoot positioning, mechanical pruning, mechanical thinning, mechanical harvesting, and the postharvest handling and utilization of mechanically harvested grapes without loss of yield or quality (Cawthon and Morris, 1977; Morris, 1985a; Morris and Cawthon, 1980a, 1980b, 1981; Morris et al., 1975, 1984).
Extraneous material in mechanically harvested grapes must be controlled. Material other than grapes (MOG) such as bark, canes, leaves, petioles, and staples is a result of shaking the vine to harvest the grapes and a function of the ease with which the berry separates from the cluster. Petrucci and Siegfried (1976) reported that the amount of MOG may be reduced by cultural practices and improved cleaning of machinery.

Muscadine grapes are unique in that an abscission layer forms as the berries mature. With some cultivars, this layer is so complete that the ripe fruit will drop in advance of the mechanical harvester's collecting mechanism. Researchers at the University of Arkansas have designed an extended collecting unit that adapts to the front of any conventional

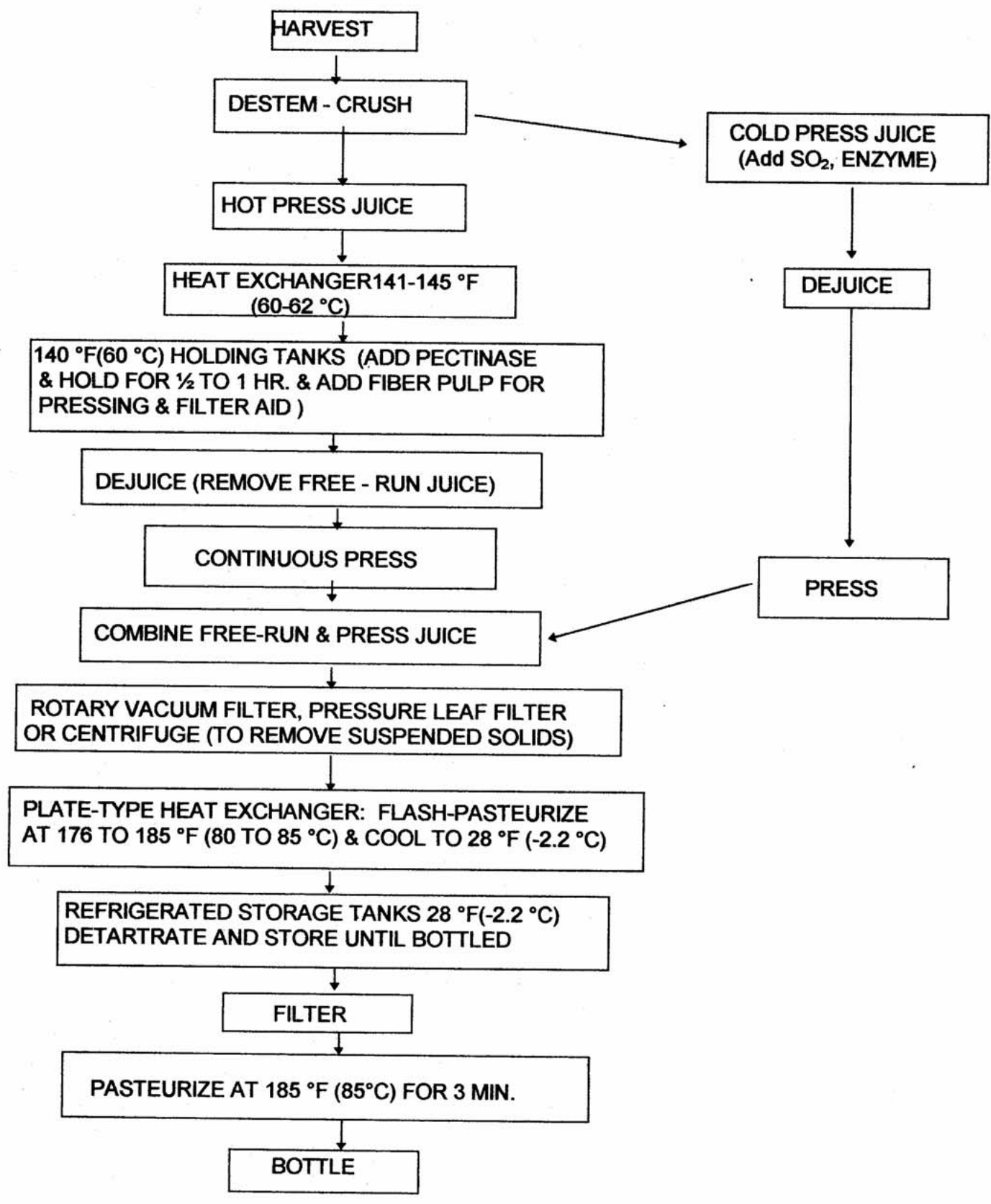

Fig. 2. The basic steps in grape juice production. Source: Dillon, C.R., J. Morris, C. Price, and D. Metz, 1994. 
commercial harvester to prevent the loss of these very mature fruits (Morris, 1983). Also, removal of the front, or first set, of beater rods in the mechanical harvester will prevent loss of mature fruit in advance of the harvester.

\section{Postharvest handling}

Mechanical harvesting and handling of most grapes cause the berries to rupture and juice and enzymes to combine which can lead to quality deterioration if not handled properly. The addition of sulfur dioxide $\left(\mathrm{SO}_{2}\right)$ to machine-harvested grapes has been shown to decrease quality loss during holding. Morris et al. (1979) reported that the addition of 80 to $160 \mathrm{ppm} \mathrm{SO}$ immediately after harvest slowed postharvest deterioration of machineharvested grapes by delaying alcohol accumulation and loss of soluble solids for $24 \mathrm{~h}$ when held at $95^{\circ} \mathrm{F}\left(35^{\circ} \mathrm{C}\right)$ or more. Sulfur dioxide will discourage microbial spoilage that might be expected at high fruit temperatures $\left(95^{\circ} \mathrm{F}\right)$ and serves as an antioxidant to prevent juice browning.

Morris et al. (1979) showed that the temperature at harvest and handling influenced the quality of machine-harvested grapes more than any other factor. They also found that mechanically harvested grapes placed in 1-ton $(0.9 \mathrm{t})$ pallet boxes after harvest did not increase in temperature for $72 \mathrm{~h}$. The initial temperature of the grapes at harvest governs the storage temperature, regardless of the external air temperature.

The type of containers used for transporting the grapes to the processing unit can also influence product quality. Whittenberger et al. (1971) and Marshall et al. (1972) reported that bulk collecting units have not reduced, and in some cases, have helped to maintain quality of the processed product. varied within a range to produce juice with uniform color from grapes harvested throughout the season. Juice quality is adversely affected if excessive extraction temperatures (exceeding $149^{\circ} \mathrm{F}$ or $65^{\circ} \mathrm{C}$ ) are used.

Harvested grapes are dumped into a hopper and then transported by augers or pumps to a rotary stemmer-crusher that separates the fruit from the stem. The crushed berries are pumped through a steam-jacketed, vacuum preheater where the pulp is heated to 141 to $145^{\circ} \mathrm{F}\left(60\right.$ to $\left.63^{\circ} \mathrm{C}\right)$ and pumped into holding tanks. At this point, slow-moving agitators mix $3.2 \mathrm{oz}(9 \mathrm{lg})$ of pectolytic enzyme and $15 \mathrm{lb}(6.8 \mathrm{~kg})$ of purified paper pulp into each ton $(0.9 \mathrm{t})$ of grapes. It takes between 30 and $60 \mathrm{~min}$ for the enzymes to break down the pectin and ready the grape pulp for pressing. This also helps to extract color from the skins and improve juice yield.

Next, a dejuicer removes $30 \%$ to $35 \%$ of the free-run juice through a 40 -mesh screen. The remaining pulp empties into a continuous screw press (Fig. 3). The free-run juice may have as much as $20 \%$ to $40 \%$ suspended solids, while the pressed juice may have only 5 to $6 \%$. The two juices are recombined, and a majority of the insoluble solids are removed by rotary vacuum filtration, pressure leaf filtration, or centrifugation. This process yields $\approx 200 \mathrm{gal}(738 \mathrm{~L})$ of juice per ton $(0.9 \mathrm{t})$ of grapes. An additional $10 \mathrm{gal}(37.8 \mathrm{~L})$ of juice (after concentration) may be obtained by breaking up the press cake, spraying it with hot water, and repressing.

After juice extraction, the argols (tartar in crude form) and tartrates must be precipitated. To accomplish this, the filtered juice is flash-heated to 176 to $185^{\circ} \mathrm{F}\left(80\right.$ to $\left.85^{\circ} \mathrm{C}\right)$ in a tubular or plate-type heat exchanger, cooled
Fig. 3. One type of continuous screw press that presses the pomace against a counterweighed plug. Another popular press for grapes is a batch press that operates by inflating an internal bag made of thick rubber (bladder press). Several types of batch presses are commercially available.

\section{Processing method}

Methods for commercial processing of grape juice have undergone continuous change since Thomas Welch made his first batch of grape juice in the family kitchen in Vineland, N.J. The continuous pressing method is used in most large commercial operations.

Hot press. Hot-press juice is produced by heating the grapes, adding pectolytic enzyme to the hot must to break down naturally occurring pectins, and using paper pulp or rice hulls to facilitate extraction of juice (Fig. 2). A hot-press method yields more juice that contains higher total solids, more nonsugar solids, higher phenolics, pigments, and other substances than a cold-press juice process.

When hot-pressing, the temperature and time in processing can be

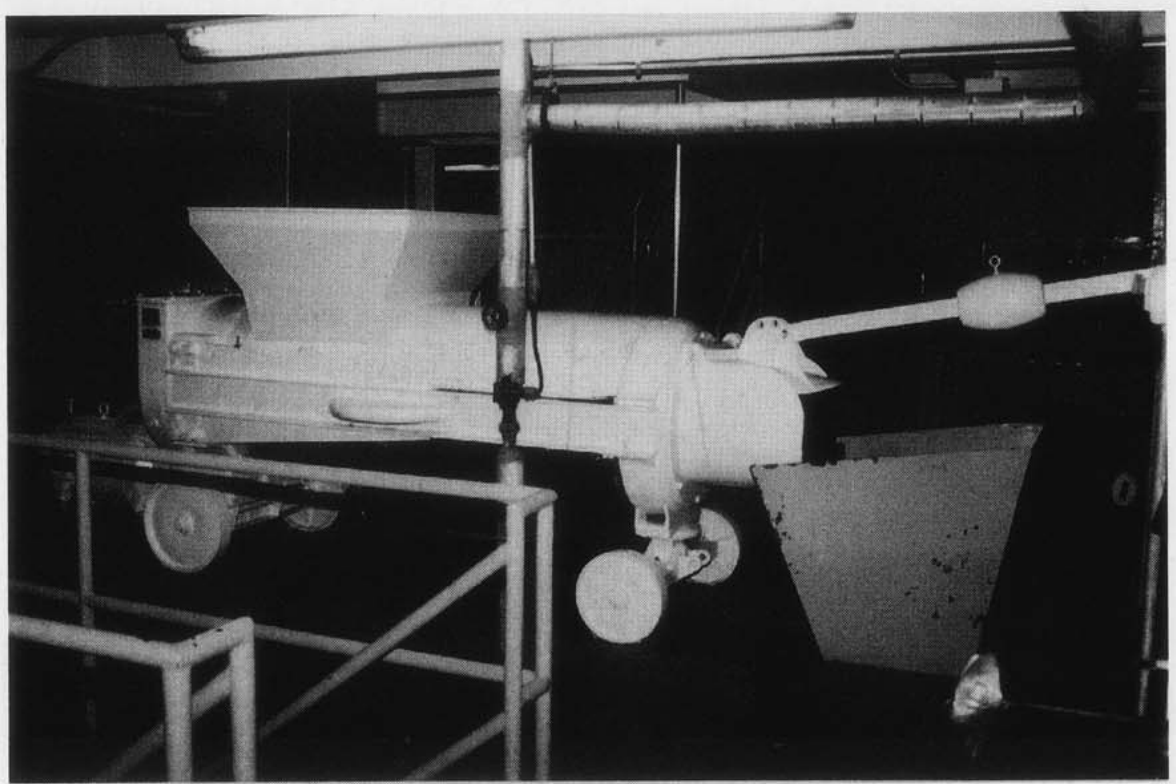


in another heat exchanger to $28^{\circ} \mathrm{F}$ ($2.2^{\circ} \mathrm{C}$ ), and placed in tanks for rapid settling of argols. The final processing into a single-strength juice or concentrate can occur once the argols have settled and the juice is racked off. The sediment can be filtered, resterilized, and stored to allow the argols to settle again for optimal recovery of juice.

The juice is finally passed through a heat exchanger (heating it to $171^{\circ} \mathrm{F}$ or $77^{\circ} \mathrm{C}$ ), into an automatic filler and then into preheated bottles. The bottles are capped, pasteurized at $185^{\circ} \mathrm{F}(85$ ${ }^{\circ} \mathrm{C}$ ) for $3 \mathrm{~min}$, cooled, and labeled.

Cold press. The only differences between this method of juice production and the hot-press method are the steps that allow for heating of the crushed grapes and addition of pectolytic enzymes to the hot must. Without these steps, the juice is a light color because the anthocyanins from the dark-skinned grapes are poorly extracted. Enzymes are added to the cold-press juice to facilitate the clarification and filtration process following cold stabilization. Juice yields from this method of processing may be only $170 \mathrm{gal}(643 \mathrm{~L})$ per ton $(0.9 \mathrm{t})$, depending on the cultivar and pressing efficiency. Muscadine grapes may only yield 130 to $140 \mathrm{gal}(492$ to $530 \mathrm{~L}$ ) of juice per ton of grapes when processed using the cold press method.

Depectinized juice can be concentrated to $72^{\circ} \mathrm{Brix}$, but most juice is concentrated to 55,65 , or $68^{\circ}$ Brix (see section on juice concentrate). Grape juice concentrate is diluted into single-strength grape juice, multifruit concentrates, and sparkling juice. It is also used to sweeten jams, jellies, yogurt, frozen fruit desserts, cereals, cookies, and other bakery products. Fruit concentrates are replacing table sugar and corn syrup for many consumers who perceive fruit concentrate as a healthier sweetener.

Investigations into the production of grapes and processing of juice have provided a variety of new ideas. Many studies and trials have been conducted to develop and determine the acceptance of grape juices and grape juice blends from new cultivars. King et al. (1988) studied the effect of maturity and carbonation on muscadine grape juice. Carbonated juices were lighter in color but equally acceptable as noncarbonated juices. A sensory panel preferred the late maturing juices with high muscadine character and low phenolic and acid levels. Sistrunk and Morris (1985) blended muscadine juices with other popular grape juices, cranberry juice, and apple juice. The dark juices were highly acceptable and retained their color and flavor quality during a 12 -month storage period. The lightest combinations (lighter muscadine with apple and 'Niagara' grape juice) were rated highest for acceptability and also remained stable during storage.

\section{Grape juice concentrate}

Grape juice is concentrated to 55 , 65 , or $68^{\circ}$ Brix and used in making grape and multifruit juices or as a sweetener in other food products and fruit spreads. Grape concentrate competes in the market with apple and other fruit juice concentrates as well as with sugar. Grape growers and their associations, in conjunction with agricultural extension programs available to them, could develop initiatives to capture a larger share of this market for grape juice concentrate. Their options could include development of new cultivars and viticultural practices suited to juice concentrate production, development of uniform standards for concentrates, and development of educational resources to broaden industry understanding of how concentrates may be used.

Concentration of juice is a vital operation of the juice processing industry, and grape juice concentrate consumption is on the rise. The USDA reports that grape concentrate consumption in the United States rose from 682,000 tons $(618,710 \mathrm{t})$ in 1985 to $>1.3$ million tons ( 1.18 million $t)$ in 1992. During that same period, California's production of concentrate went from 350,000 tons $(317,520 t)$ to 652,000 tons $(591,494 \mathrm{t})$.

Historically, evaporation has been the most important process for concentrating grape juice. Many types of evaporators are available, but all have essentially the same components (Hartel, 1992). The basic makeup of evaporators includes a heat transfer surface, a feed distribution device, a liquid-vapor separator, and a condenser. It is desirable to heat grape juice for the shortest time possible and to cool it rapidly in order to minimize the effect of heat on flavor, aroma, and sugar components. The following systems are used by juice processors and are often coupled with essence recov- ery systems. Recovery systems are often activated carbon columns that adsorb flavor and aroma compounds. Steam stripping can then be used to selectively remove these compounds for later return to the concentrate or for other uses.

Rising film evaporator. A rising film evaporator or long-tube vertical is sometimes used for juice processing. This evaporator has the advantage of short evaporation times due to high heat transfer rates through thin films at high temperature differentials. The evaporator consists of a steam chest with bundled tubes inside. The feed stream is heated and introduced into the bottom of the tubes where it vaporizes. Under vacuum, the fluid rises in a thin film along the tubes. It then enters a vapor-liquid separator, and the vapor enters a condenser to be liquefied or is passed through a carbon column.

Falling film evaporator. A falling film is almost identical to a rising film evaporator except that fluid is pumped over the top of the tube bundle. This is the most popular type of evaporator because it can handle more viscous fluids than the rising film type and can be operated at lower temperature differentials.

Plate evaporators. Plate evaporators operate similarly to plate heat exchangers. The fluid to be evaporated passes on one side of a plate, and steam flows on the other side. The fluid is superheated and passes into a flash chamber. The vapor flashes off, separating the product and vapor. High-viscosity fluids can be efficiently concentrated in these evaporators, with possible concentration above $60^{\circ}$ Brix.

Centrifugal or conical evapoRATORS. These evaporators are relatively new. A thin film is produced by centrifugal force in single or nested cones that have steam on the alternate side to provide a heat transfer surface. The system operates under vacuum which allows the total time on the juice transfer surface to be as little as 0.5 seconds with only a small increase in product temperature. The centrifugal evaporators are good for extremely heat-sensitive or high-viscosity products. These evaporators not only concentrate but also distill, degas, and deodorize liquids that have a high sensitivity to heat. Their major drawbacks are low capacity and high capital cost. 
Freeze concentration. This process is based on the physical phenomenon of freezing point depression. Pure water freezes at a temperature of $32^{\circ} \mathrm{F}\left(0^{\circ} \mathrm{C}\right)$, and the temperature lowers when dry solids are dissolved in it. In freeze concentration, there are three basic units used: 1) a freezer or crystallizer that produces a slurry of ice crystals, 2) a device for separating the ice crystals from the slurry (a centrifuge, wash column, or filter press), and 3 ) a refrigeration unit to reduce the heat from fusion and the heat generated by friction from hydraulic flow, wall scraping, and agitation of the slurry. Freeze concentration avoids the heat-related difficulties associated with evaporation methods and is capable of concentrating most fruit juices to $50^{\circ}$ Brix without appreciable loss of taste, aroma, color, or nutritive value. Even with these advantages, freeze concentration has not been used commercially since 1966 because of its relative high capital cost.

Thomas Welch would be amazed today at what has become of his kitchen enterprise to produce communion juice. From its development as a completely American product, it has risen to an American institution in its many forms. Many preharvest, postharvest, harvesting, handling, and processing factors impact the quality of commercial grape juice. Today, we have scientific evidence for benefits of grape juice to human health, and we have developed new methods of producing, preserving, and using juice. In the future, the nutritional quality and human health benefits of grapes and grape products will become even more important to the consumer.

\section{Literature cited}

Acree, T.E., E.H. Alvin, R. Nishida, and S. Watanabe. 1990. O-aminoacetophenone, the "foxy" smelling component of lubruscana grapes, p. 49-52. In: Y. Bessiere and A.F. Thomas (eds.). Flavor science and technology. Wiley, New York.

Berg, V.A. 1940. Composition of grapes. Kult. Rast. 7:105

Blevins, J.M. and J.R. Morris. 1997. Health benefits of wine and grape juice. HortTechnology 7(3):228-233.

Boyle, J.A. and L. Hsu. 1990. Identification and quantitation of ellagic acid in muscadine grape juice. Amer. J. Enol. Viticult. $41(1): 43-47$.

Horlechnology • October-December $1998 \quad 8(4$
Cash, J.N., W.A. Sistrunk, and C.A. Stutte. 1977. Changes in nonvolatile acids of Concord grapes during maturation. J. Food Sci. 42:543-544.

Cawthon, D.C. and J.R. Morris. 1977. Yield and quality of 'Concord' grape as affected by pruning severity, nodes per bearing unit, training system, shoot positioning and sampling date in Arkansas. J. Amer. Soc. Hort. Sci. 102:760-767.

Cawthon, D.L. and J.R. Morris. 1983. Uneven ripening of 'Concord' grapes. Ark. Farm Res. 32(1):9.

Chazanof, W. 1977. Welch's grape juice: From corporation to co-operative. Syracuse Univ. Press, New York.

Dale, A., E.J. Hanson, D.E. Yarborough, R.J. McNicol, E.J. Stang, R. Brennan, J.R. Morris, and G.B. Hergert. 1995. Mechanical harvesting of berry crops, p. 328-48. In: J. Janick (ed.). Horticultural reviews. vol. 16. Grapes. Wiley, New York.

Dillon, C.R., J. Morris, C. Price, and D. Metz. 1994. The technological and economic framework of wine and juice production in Arkansas. Univ. of Ark., Fayetteville, Agr. Expt. Sta. Bul. 941.

Ector, B.J., J.B. Magee, C.P. Hegwood, and M.J. Coign. 1996. Resveratrol concentration in Muscadine berries, juice, pomace, purees, seeds, and wines. Amer. J. Enol. Viticult. 47(1):57-62.

Flora, L.F. 1978. Influence of heat, cultivar, and maturity of the anthocyanidin3,5-diglucosides of muscadine grapes. J. Food Sci. 43:1819-1821.

Frankel, E.N., A.L. Waterhouse, and J.E. Kinsella. 1993. Inhibition of human LDL oxidation by resveratrol. Lancet 341:11031104.

Fuleki, T., E. Pelayo, and R.B. Palaboy. 1993. Carboxylic acid composition of authentic varietal and commercial grape juice. J. Assn. Official Analytical Chem. Intl. 76(3):591-600.

Garrido, V.M., C.A. Sims, M.R. Marshall, and R.P. Bates. 1993. Factors influencing ellagic acid precipitation in muscadine grape juice during storage. J. Food Sci. 58(1):193-196.

Goldy, R.G., W.E. Ballinger, and E.P. Maness. 1986. Fruit anthocyanin content of some Euvitis X Vitisrotundifolia hybrids. J. Amer. Soc. Hort. Sci. 111:955-960.

Hartel, R.W. 1992. Evaporation and freeze concentration, p 341-392. In: D.R. Heldman and D.B. Lund (eds.). Handbook of food engineering. Marcel Dekker, New York.

Hartmann, B.G. and L.M. Tolman. 1918. Concord grape juice; manufacture and chemical composition. USDA Bul. 656.

Jang, M., L. Cai, G.O. Udeani, K.V. Slowing, C.F. Thomas, C.W.W. Beecher, H.H.S. Fong, N.R. Farnsworth, A.D. Kinghorn, R.G. Mehta, R.C. Moon, and J.M. Pezzuto. 1997. Cancer chemopreventive activity of resveratrol, a natural product derived from grapes. Science. 275:218-220.

Johnston, T.V. and J.R. Morris. 1996. Circular dichroism and spectroscopic studies of Vitis vinifera cv. Cabernet Sauvignon and Vitis rotundifoliacv. Noble red wine liquid chromatographic fractions. Amer. J. Enol. Viticult. 47(3):23-28.

King, R.C., C.A. Sims, L.F. Moore, and R.B. Bates. 1988. Effects of maturity, skin contact and carbonation on the quality of sterile-filtered white muscadine grape juice. J. Food Sci. 53(5):1474-1476, 1485.

Lamikanra, O. 1988. Development of anthocyanin pigments in muscadine (Vitis rotundifolia Michx.) grapes. HortScience 23:597-599.

Lin, T.Y. and R.P. Vine. 1990. Identification and reduction of ellagic acid in muscadine grape juice. J. Food Sci. 55(6):16071609.

Marshall, D.E., J.H. Levin, B.F. Cargill, and R.T. Wittenberger. 1972. Quality of bulk handled 'Concord' grapes. 1972 Annu. Mtg. Amer. Soc. Enol., Univ. of Calif, Davis.

Maas, J.L., G.J.Galletta, and G.D. Stoner. 1991. Ellagic acid, an anticarcinogen in fruits, especially strawberries: A review. HortScience 26:10-14.

Montgomery, M.W., F.G.R. Reyes, C. Cornwell, and D.V. Beavers. 1982. Sugars and acid analysis and effect of heating on color stability of Northwest Concord grape juice. J. Food Sci. 47:1883-1885, 1891.

Moore, J.N., J.R. Morris, and J.R. Clark. 1993. 'Sunbelt', a new juice grape for the south-central United States. HortScience 28:859-860.

Morris, J.R. 1981. Problems that inhibit the expansion of the commercial muscadine grape industry. Fruit South 5(2):28-29.

Morris, J.R. 1983. Influence of mechanical harvesting on quality of small fruits and grapes. Hortscience 18(4):412-416.

Morris, J.R. 1985a. Approaches to more efficient vineyard management. HortScience 20:1008-1013.

Morris, J.R. 1985b. Grape juice: Influences of preharvest, harvest, and postharvest practices on quality, p. 129-176. In: Pattee (ed.). Evaluation of quality of fruits and vegetables. AVI Publishing Co., Conn. 
Morris, J.R. 1990. Fruit and vegetable mechanization. Food Technol. 44(2):97101.

Morris, J.R. 1996. Evaluating drip irrigation in Eastern vineyards. Wine East. 24(4):16-21. Nov-Dec.

Morris, J.R. and D.L. Cawthon. 1980a. Mechanical trimming and node adjustment of cordon-trained 'Concord' grapevines. J. Amer. Soc. Hort. Sci. 105(3):310313.

Morris, J.R. and D.L. Cawthon. 1980b. Yield and quality response of 'Concord' grapes to training systems and pruning severity in Arkansas. J. Amer. Soc. Hort. Sci 105(3):307-310.

Morris, J.R. and D.L. Cawthon. 1981. Yield and quality response of 'Concord' grapes (Vitis labrusca L.) to mechanized vine pruning. Amer. J. Enol. Viticult. $32: 280-282$.

Morris, J.R. and K. Striegler. 1996. Grape juice:Factors that influence quality, processing technology, and economics, p. 198. In: L.P. Somogyi, D.M. Barrett, and Y.H. Hui. (eds.). Major processed products. vol. 2. Technomic Publ., Lancaster, Pa.

Morris, J.R., D.L. Cawthon, and J.W. Fleming. 1975. Effect of mechanical pruning on yield and quality of 'Concord' grapes. Ark. Farm Res. 24(3):12.

Morris, J.R., D.L. Cawthon, and J.W. Fleming. 1979. Effects of temperature and $\mathrm{SO}_{2}$ addition on quality and postharvest behavior of mechanically harvested juice grapes in Arkansas. J. Amer. Soc. Hort. Sci. 104:166

Morris, J.R., D.L. Cawthon, and C.A. Sims. 1984. Long-term effects of pruning severity, nodes per bearing unit, training system and shoot positioning on yield and quality of 'Concord' grapes. J. Amer. Soc. Hort. Sci. 109(5):676-683.

Nagel, C.W. and L.W.Wulf. 1979. Changes in the anthocyanins, flavonoids and hydroxycinnamic acid esters during fermentation and aging of Merlot and Cabernet Sauvignon. Amer. J. Enol. Viticult. 30:111-116.

Pace-Asciak, C.R., F. Hahn, E.P. Dimandis, G. Soleas, and D.M. Goldberg. 1995. The red wine phenolics trans-resveratrol and quercetin block human platelet aggregation and eicosanoid synthesis: Implication for protection against coronary heart disease. Clin. Chimica Acta 235(2):207-219.

Pederson, C.S. 1971. Grape juice. p. 234271. In: D.K. Tressler and M.A. Joslyn (eds.). Fruit and vegetable Juice processing technology. 2nd ed., AVI Publishing, Conn.

Petrucci, V.E. and R. Siegfried. 1976. Research note: The extraneous matter in mechanically harvested wine grapes. Amer. J. Enol. Viticult. 27:40.

Ribereau-Gayon, P. 1959. Recherches sur les anthocyannes des vegetaux. appliocation au genre Vitis, p. 114. Librairie Generale Enseignement, Paris.

Robinson, W.B., N.J. Shaulis, and C.S.
Pederson. 1949. Ripening studies of grapes grown in 1948 for juice manufacture. Fruit Prod. J. 29:36.

Sastry, L.V.L. and R.G. Tischer. 1952. Stability of the anthocyanin pigments in Concord grape juice. Food Technol. 6:264.

Shaulis, N.J., H. Amberg, and D. Crowe. 1966. Response of 'Concord' grapes to light exposure and Geneva double curtain training. Proc. Amer. Soc. Hort. Sci. 89:268-280.

Sims, C.A. and J.R. Morris. 1985. $\mathrm{pH}$ effects on the color of wine from two grape species. Ark. Farm Res. 34(2):9.

Sistrunk, W.A. and J.R. Morris. 1985. Quality acceptance of juices of two cultivars of muscadine grapes mixed with other juices. J. Amer. Soc. Hort. Sci. 110:328332.

Threllfall, R. and J. R. Morris. 1997. Effect of enological and viticultural methods on resveratrol content of wine. Proc. 4th Intl. Symp. Cool Climate Viticult. and Enol. Amer. Soc. Enol. Viticult./Eastern Sec. Rochester, N.Y. p. VI 100-102

Tressler, D.K. 1971. Historical and economic aspects of the juice industry, p. 1516. In: D.K. Tressler and M.A. Joslyn (eds.). Fruit and vegetable juice processing technology. 2nd ed. AVI Publishing, Conn.

Whittenberger, R.T., D.E. Marshall, J.H. Levin, and B.F. Cargill. 1971. Bulk handling of 'Concord' grapes for processing: Quality evaluation. Annu. Mtg. Amer. Soc. Agr. Eng., Wash. State Univ., Pullman. 